\title{
AVALIAÇÃO DO DESEMPENHO DE CÉLULAS COMBUSTÍVEIS MICROBIANAS COM MEMBRANAS ANIÔNICAS E CATIÔNICAS
}

\author{
G. V. B. MONTZEL ${ }^{1}$, R. B. BASTOS ${ }^{1}$, D. V. MESQUITA ${ }^{1}$, F. B. SANTANA ${ }^{1}$, C. S. \\ OGRODOWSKI ${ }^{1}$ \\ ${ }^{1}$ Universidade Federal do Rio Grande - FURG, Escola de Química e Alimentos - EQA \\ E-mail para contato: danivdemesquita@ hotmail.com
}

\begin{abstract}
RESUMO - Células combustíveis microbianas (CCM) são dispositivos que produzem energia através da degradação da matéria orgânica. Desse modo, são caracterizadas como uma tecnologia emergente para o tratamento de efluentes ao mesmo tempo em que é uma fonte alternativa de energia. As modificações dos materiais que compõem uma célula combustível microbiana são exemplos de mudanças estudadas com o objetivo de aumentar a geração de energia elétrica. Nesse contexto, o presente trabalho avaliou o desempenho da CCM operando com diferentes membranas (catiônicas ou aniônicas). Os parâmetros resistivos das células foram avaliados pelas análises eletroquímicas: curva de polarização e voltametria cíclica. Os resultados indicaram desempenho superior da configuração com a membrana de troca aniônica com corrente máxima e potência máxima de $3032,11 \mathrm{~mA} / \mathrm{m}^{2}$ e $56,7 \mathrm{~mW}$ a $56 \Omega$, respectivamente.
\end{abstract}

\section{INTRODUÇÃO}

A necessidade de exploração e desenvolvimento de novas tecnologias para a geração de energia que não afetem negativamente o meio ambiente é um reflexo do crescimento acelerado da população e da indústria que, como consequência, causam maior demanda de energia e de tratamento dos resíduos. Com o objetivo de atender a essas necessidades, a célula combustível microbiana (CCM) produz de forma alternativa energia, através da degradação da matéria orgânica, oferecendo a possibilidade de solucionar problemas ambientais e econômicos.

Nesse contexto, foi avaliado o desempenho de células combustíveis microbianas utilizando membranas catiônicas ou aniônicas, com o objetivo de identificar a influência da membrana no desempenho na geração de energia.

\section{REFERENCIAL TEÓRICO}

A célula combustível microbiana é um biorreator composto por dois compartimentos, anódico e catódico, possuindo um eletrodo cada, conectados externamente a um circuito elétrico, e separados por uma membrana de íon seletiva. A reação de oxirredução, segundo Logan (2008), é catalisada pelos micro-organismos presentes no efluente utilizado. 
De acordo com Logan et al. (2006), na configuração com a membrana catiônica, a partir da oxidação da matéria orgânica realizada pelas bactérias, ocorre o desprendimento de prótons para a solução. Estes, por sua vez, são transportados através da membrana para a câmara catódica, completando o circuito e permitindo a reação de oxirredução.

A membrana aniônica funciona de maneira semelhante, porém, segundo Fan et al. (2007), o próton liberado pela oxidação da matéria orgânica se associa aos ânions presentes na solução anódica, como carbonato $\left(\mathrm{CO}_{3}{ }^{2-}\right)$ e hidrogenofosfato $\left(\mathrm{HPO}_{4}{ }^{2-}\right)$. Este é então transportado até o compartimento catódico através da membrana, onde é dissociado. Isso permite a execução de reação de oxirredução enquanto os ânions retornam através da membrana para o compartimento anódico.

\section{MATERIAIS E MÉTODOS}

Foram analisadas quatro células combustíveis microbianas, duas utilizando membrana de troca catiônica (CMI-7000) e duas com membrana de troca aniônica (AMI-7001, ambas da Membranes International Inc.). A célula possui duas câmaras de $20 \mathrm{~mL}$ cada, construídas com peças moduladas de acrílico. Cada câmara apresenta um eletrodo de placa de grafite com área de $10,05 \mathrm{~cm}^{2}$ acoplada a telas de aço inoxidável 304 para suporte do eletrodo. A Figura 1 ilustra a configuração do reator.

Figura 1 - Representação da célula de combustível microbiana.

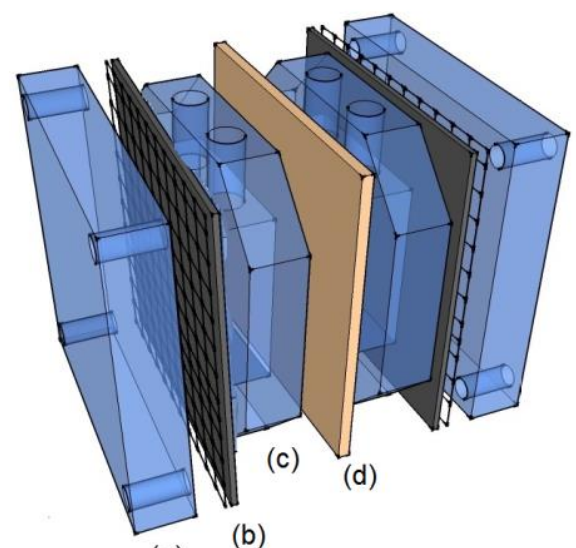

(a)

Legenda: (a) parede externa da célula; (b) eletrodo de placa de grafite e tela de aço; (c) câmara anódica ou catódica; (d) membrana íon seletiva.

Os eletrodos são conectados a um circuito elétrico com resistência externa inicial de $1000 \Omega$, variando posteriormente para 580,180 e $56 \Omega$. A aquisição de dados foi executada através da medição da diferença de potencial na resistência externa por um micro controlador Arduino Due. Os dados obtidos eram armazenados através do software Coolterm.

O compartimento catódico foi preenchido por solução de ferricianeto de potássio $\left(\mathrm{K}_{3} \mathrm{Fe}(\mathrm{CN})_{6}\right)$ de concentração $16,46 \mathrm{~g} \mathrm{~L}^{-1}$, funcionando como aceptor de elétrons, e sua troca 
total foi realizada diariamente. O compartimento anódico foi preenchido com inóculo na proporção de 2:1 de sedimento marinho de dragagem do Porto de Rio Grande e meio de cultivo utilizado por Teleken (2013), tendo retirada diária de alíquota de $5 \mathrm{~mL}$ e reposição de mesma quantidade de meio de cultivo.

A operação das células ocorreu em um período de 26 dias, a uma temperatura controlada de $35,5^{\circ} \mathrm{C}$ e pH entre 7 e 7,5 , sem a agitação, condições ideais para a operação, segundo Mesquita (2016).

O desempenho das configurações, com membrana catiônica ou membrana aniônica, foi comparado, através dos dados de densidade de corrente ao longo do tempo e das análises eletroquímicas curva de polarização e voltametria cíclica executadas em potenciostato Palm Sens3.

\section{RESULTADOS E DISCUSSÕES}

Os dados de densidade de corrente apresentaram desempenho superior das células com membrana aniônica, acentuado pela utilização das resistências externas de 180 e $56 \Omega$, conforme representado pela Figura 2. Isso pode ser explicado pelo valor mais baixo da resistência externa ser mais próximo ao valor da resistência interna quando a CCM foi operada com a membrana aniônica.

Figura 2 - Gráfico da densidade de corrente por tempo.



As curvas de polarização apresentaram, também, um desempenho superior da membrana de troca aniônica, conforme representado pelas Figuras 3 e 4 . Com os dados da Figura 3, foram calculadas as resistências internas de 297, 164, 243 e $216 \Omega$ para a membrana aniônica e 531, 272, 177 e $209 \Omega$ para a membrana catiônica, referentes as resistências de $1000,580,180$ e $56 \Omega$, respectivamente. 


\section{Congresso Brasileiro de Engenharia Química \\ em Iniciação Científica \\ UFSCar - São Carlos - SP \\ 16 a 19 de Julho de 2017}

Figura 3 - Curvas de polarização da tensão por corrente para as células com membranas aniônicas e catiônicas.
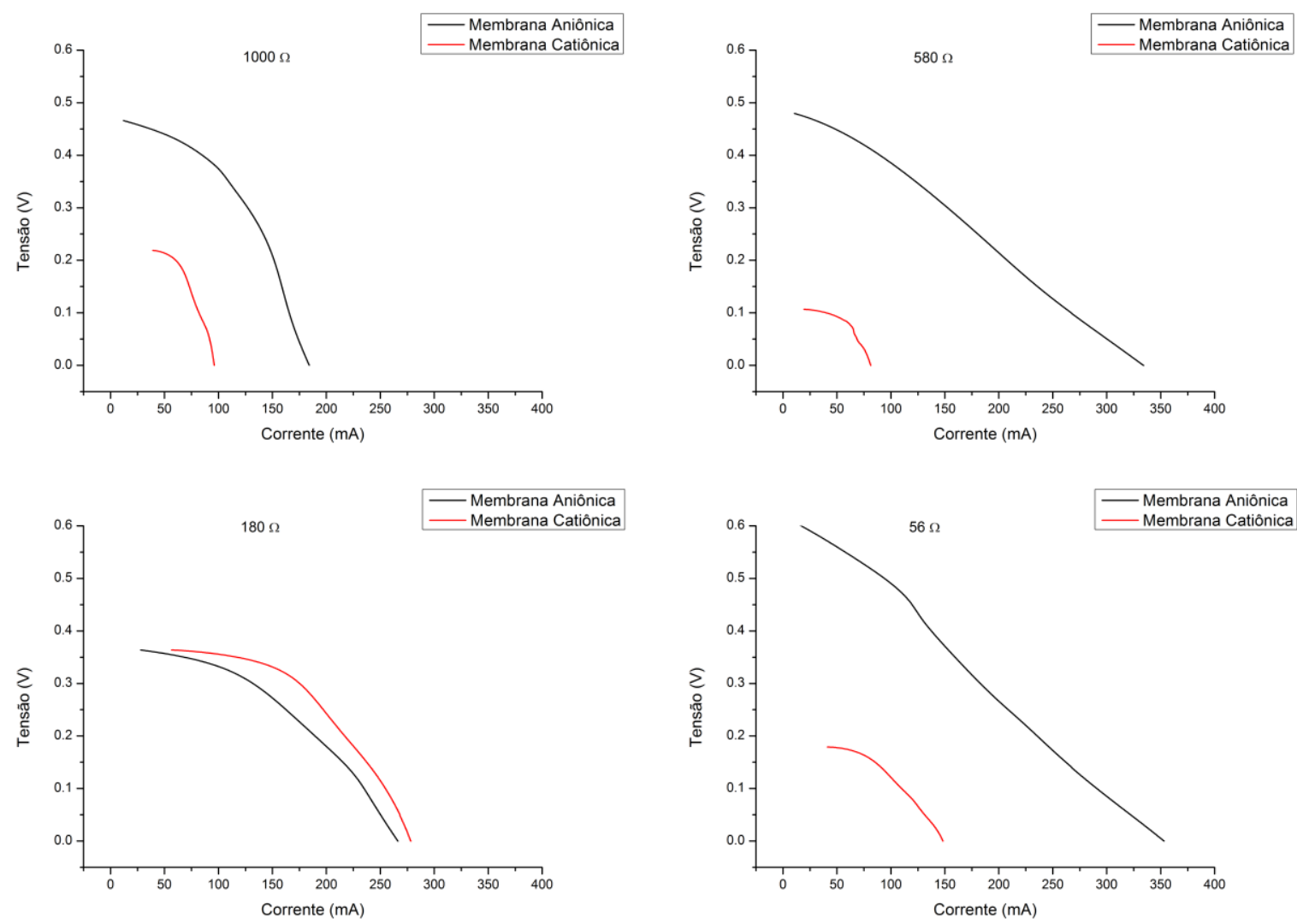

Na Figura 4 são representadas as potências máximas que cada configuração de célula atingiu, sendo $56,7 \mathrm{~mW}$ a $56 \Omega$ para a célula com membrana aniônica e 52,6 $\mathrm{mW}$ a $180 \Omega$ na configuração com membrana catiônica.

Na resistência de $180 \Omega$, foi possível observar que a membrana catiônica apresentou desempenho superior, uma vez que obteve potência máxima de $52,6 \mathrm{~mW}$ enquanto a aniônica obteve apenas 40,9 $\mathrm{mW}$. Esse comportamento pode ser explicado pela proximidade do valor da resistência externa ao da resistência interna conforme apresentado por Logan (2008).

Já a membrana aniônica apresentou maior potência na resistência externa de $56 \Omega$. Entretanto, é possível observar que a relação da diferença das resistências com a potência máxima não afeta o desempenho da célula da mesma forma que a observada em uma célula com a membrana catiônica, uma vez que a potência máxima alcançada foi de $56,7 \mathrm{~mW}$ para a resistência de $56 \Omega$. 
Figura 4 - Curvas de polarização da potência por corrente para as células com membranas aniônicas e catiônicas.
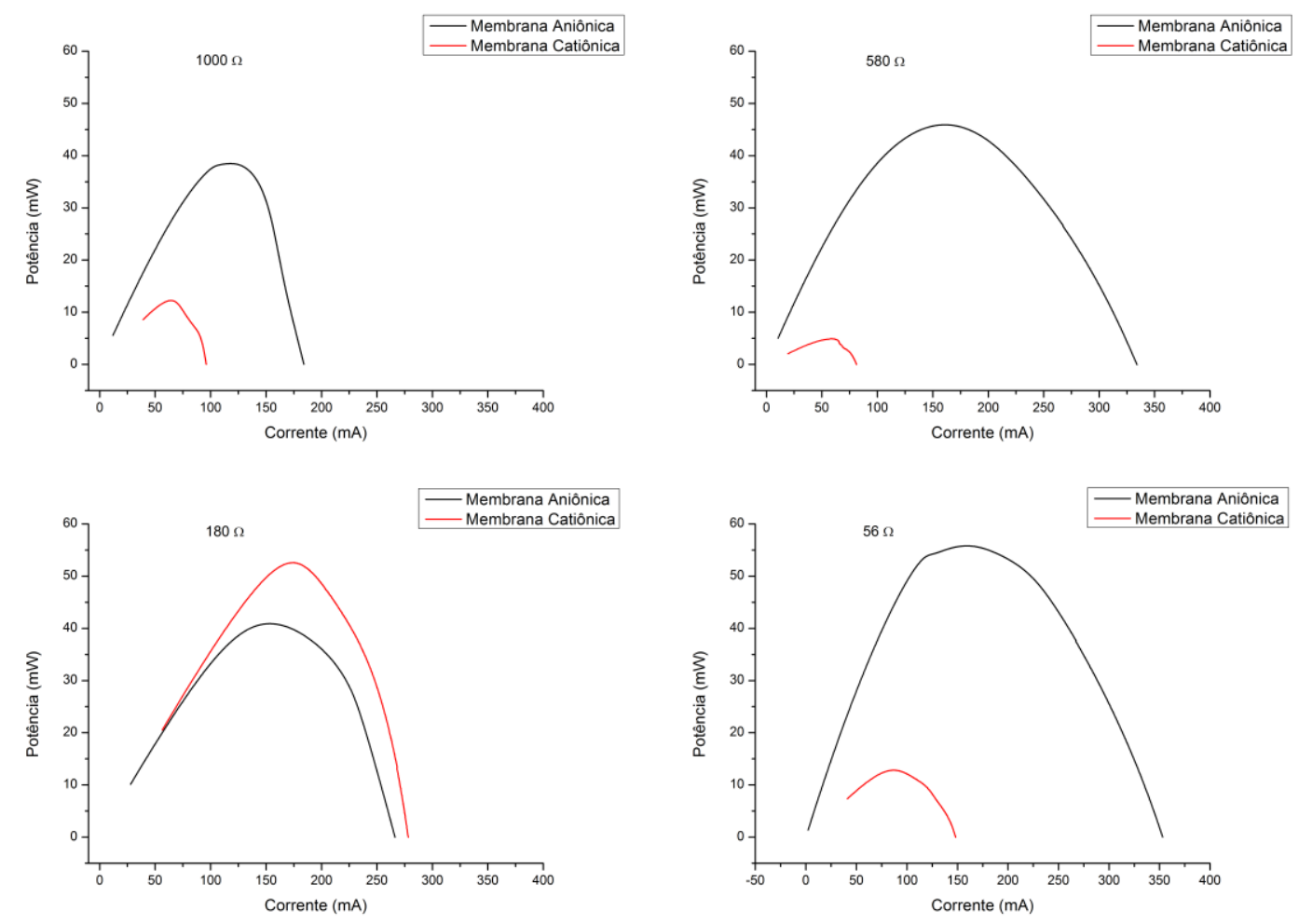

$\mathrm{Na}$ voltametria cíclica, apresentada na Figura 5, observa-se que a curva da célula com membrana aniônica apresenta maior inclinação o que indica melhor o desenvolvimento de biofilme nessa configuração de reator em comparação com a membrana catiônica.

Figura 5 - Efeito da membrana (catódica ou anódica) na resposta das análises de voltametria cíclica.

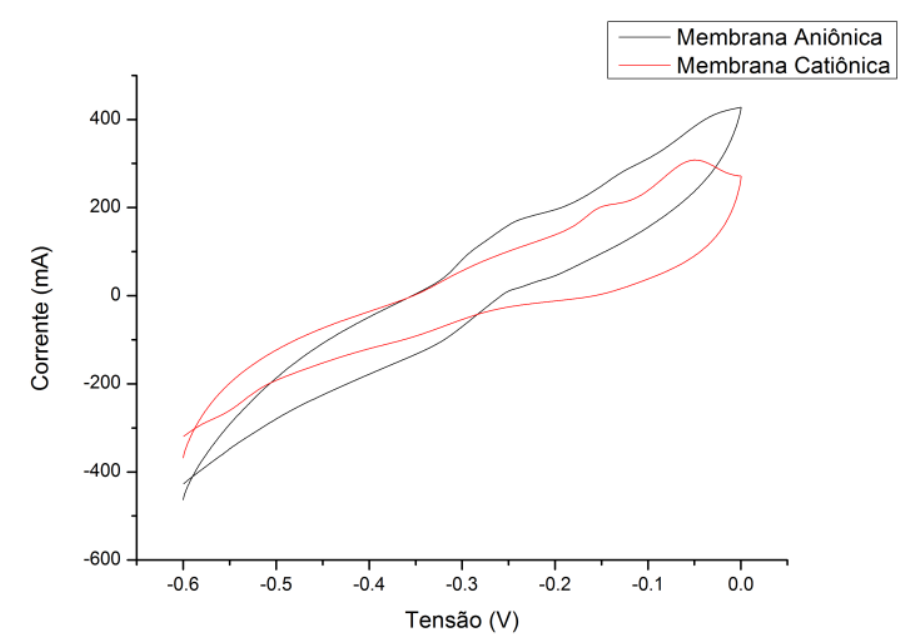


Os resultados obtidos estão de acordo com Kim et al. (2007) que comparou as membranas estudadas, juntamente com outros modelos, em configuração diferente de reator. $\mathrm{O}$ autor concluiu que a membrana de troca aniônica apresentou desempenho superior com densidade de potência de até $610 \mathrm{~mW} / \mathrm{m}^{2}$ devido ao efeito tampão do íon fosfato.

\section{CONCLUSÕES}

Com base na análise dos dados, foram observados resultados superiores da célula com membrana de troca aniônica, obtendo corrente máxima de $3032,11 \mathrm{~mA} / \mathrm{m}^{2}$ a $56 \Omega$ e potência máxima de $56,7 \mathrm{~mW}$ a $56 \Omega$. Desse modo, conclui-se que a membrana de troca aniônica tem desempenho superior frente à membrana de troca catiônica nas condições testadas.

Para trabalhos futuros pode ser avaliada a troca iônica que ocorre dentro da célula, para verificar a influência dos íons específicos no transporte de carga. Além disso, podem ser executados testes com uma faixa de $\mathrm{pH}$ diferente que favoreça a formação de íons responsáveis pelo transporte de carga, bem como estudar o efeito tampão do íon fosfato.

\section{REFERENCIAS}

FAN, Y.; HU, H.; LIU, H. Sustainable Power Generation in Microbial Fuel Cells Using Bicarbonate Buffer and Proton Transfer Mechanisms. Environ. Sci. Technol., v. 41, p. 8154-8158, 2007.

KIM, J. R.; CHENG, S.; OH, S. E.; LOGAN, B. E. Power Generation Using Different Cation, Anion, and Ultrafiltration Membranes in Microbial Fuel Cells. Environ. Sci. Technol., v. 41, p. 1004-1009, 2007.

LOGAN, B. E. Microbial Fuel Cells. New Jersey: Wiley \& Sons, 2008.

LOGAN, B. E.; HAMELERS, B.; ROZENDAL, R.; SCHRÖDER, U.; KELLER, J.; FREGUIA, S.; AELTERMAN, P.; VERSTRAETE, W.; RABAEY, K. Microbial fuel cells: methodology and technology. Environ. Sci. Technol., v. 40, p. 5181-5192, 2006.

MESQUITA, D. V. Produção de energia elétrica em célula combustível microbiológica com sedimento de dragagem do Porto do Rio Grande. Dissertação de mestrado. Universidade Federal do Rio Grande (2016).

TELEKEN, J. T., Modelagem matemática da geração de corrente elétrica em uma célula combustível microbiana inoculada com micro-organismos marinhos. Dissertação de Mestrado. Universidade Federal de Santa Catarina (2011). 